\title{
Cannabinoid as Potential Aromatase Inhibitor Through Molecular Modeling and Screening for Anti-Cancer Activity
}

Sudipta Baroi ${ }^{1}$, Achintya Saha ${ }^{2}$, Ritesh Bachar ${ }^{3}$ and Sitesh C Bachar ${ }^{4}$

\author{
${ }^{1}$ Department of Pharmaceutical Technology, Faculty of Pharmacy, University of Dhaka \\ Dhaka-1000, Bangladesh \\ ${ }^{2}$ Department of Chemical Technology, Pharmaceutical \& Fine Chemical Technology Division \\ University of Calcutta, India \\ ${ }^{3}$ Department of Pharmacy, School of Science and Engineering, University of Information Technology \\ and Sciences (UITS), Dhaka-1212, Bangladesh \\ ${ }^{4}$ Department of Pharmacy, Faculty of Pharmacy, University of Dhaka, Dhaka-1000, Bangladesh
}

(Received: April 15, 2020; Accepted: June 2, 2020; Published (web): June 28, 2020)

\begin{abstract}
Inhibition of aromatase (CYTP450), a key enzyme in the estrogen biosynthesis, could result in regression of estrogen-dependent tumors and even prevent the promotion of breast cancer. The present research has been designed for searching a potent chemical moiety from natural sources to inhibit aromatase enzyme, the overfunctionality of which causes the breast cancer. Cannabis sativa contains a very much promising group of cannabinoids with more than 66 compounds with reported anticancer property and for the search of a target specific potent aromatase inhibitor, 61 cannabinoids from $C$. sativa were selected. The Structures Data File (SDF) of these ligand molecules were subjected to docking studies at the binding site of aromatase X-ray crystallographic structure based on lower resolution of the protein crystal structure and higher docking accuracy, predicted by calculating the correlation between experimental activities and Glide dock scores and compared with the standard aromatase ligand androstenedione and aromatase inhibitor fadrozole with existing drug for breast cancer treatment. The best docked pose of each ligand was selected on the basis of the highest dock score related to the binding free energies of the internal dataset compounds as compared to their observed activities. Apart from the hydrogen bond formation with the oxygen present on the aromatic ring system, the other parts of the molecules are stabilized by hydrophobic interactions with non-polar amino acid residues (Ile133, Phe134, Phe221, Trp224, Ile305, Ala306, Ala307, Val369, Val370, Leu372, Val373, Met374 and Leu477). From the screening results of the cannabinoid analogs, 21 out of 61 were found to have an acceptable docking score in comparison to the standards, androstenedione and fadrozole. The pharmacokinetic filters like absorption, distribution, metabolism and excretion and toxicity (ADMET) property determination were applied to select drug-like compounds. Among them three compounds were found to reveal the most promising drug like activity, which were cannabidiorcol (CN 17, CBD-C1), cannabitriol (CN 43, CBT) and cannabiripsol (CN 55, CBR). The ani-cancer activity of the target compounds was performed against brine shrimp lethality biassay, where cannabidiorcol exhibited significant $\mathrm{LC}_{50}$ value of $0.348 \pm 0.002 \mu \mathrm{g} / \mathrm{ml}\left(\mathrm{R}^{2}=0.9853\right)$ which is almost similar to vincristine sulfate $\left(\mathrm{LC}_{50}=0.316 \pm 0.003 \mu \mathrm{g} / \mathrm{ml}, \mathrm{R}^{2}=0.9882\right)$. Compound cannabitriol also showed promisimg cytotoxicity $0.650 \pm 0.004 \mu \mathrm{g} / \mathrm{ml}\left(\mathrm{R}^{2}=0.9882\right)$ in comparison to the reference standard. But cannabiripsol demostrated relatively weaker activity $12.95 \pm 1.234 \mu \mathrm{g} / \mathrm{ml}\left(\mathrm{R}^{2}=0.9897\right)$. It can be concluded that the lead compounds may be developed as potent aromatase inhibitor performing their further biological evaluation.
\end{abstract}

Key words: Molecular docking, chemometric analysis, cannabinoids, breast cancer, armoatase inhibitor, Cannabis sativa, cytotoxicity, brine shrimp lethality.

\section{INTRODUCTION}

Now a days, the most common type of cancer is breast cancer resulting with more than 234,000 new cases reported in the United States in $2015 .{ }^{1}$ It is categorized as hormone-depended and independent

Correspondence to: Sitesh C Bachar

Email: bacharsc@du.ac.bd; bacharsc63@gmail.com

Dhaka Univ. J. Pharm. Sci. 19(1): 47-58, 2020 (June)

DOI: https://doi.org/10.3329/dujps.v19i1.47818 simulation state of various hormone receptor subtypes. $^{2}$ In hormone-dependent cases of breast cancer, estrogen has been reported to play a crucial role through various mechanisms which can induce and proliferate the breast cancer. ${ }^{2}$ This helps to provoke the intracellular signaling cascades and resulting in the development of tumors. ${ }^{3,4}$ Estrogens are the causes of cancer, which can synergically 
accelerate the cell division, at the time of DNA repairing phase by generating quinines via their metabolic pathway. ${ }^{5}$ Estrogen-dependent carcinomas were reported in near $60 \%$ of premenopausal and $75 \%$ of post-menopausal breast cancer patients. ${ }^{6}$ In this background, the inhibition of aromatase, the rate limiting enzyme in the estrogen biosynthesis pathway can help to control the growth and development of estrogen-dependent tumors. Basically, aromatase is a Cytochrome P450 enzyme which converts cholesterol to estradiol E2, the most biologically active estrogen. ${ }^{7}$ Moreover, such inhibition may reduce the estradiol level in breast tissue, which can prevent the tumor promotion process. ${ }^{5}$

Aminoglutethimide and testololactone are the first-generation aromatase inhibitors, related with unspecific action that leads to induction of various kind of side effects. ${ }^{8}$ Recent FDA- approved drugs, such as exemestane ${ }^{9}$ as an steroid inhibitor, letrozole $^{10}$ and anastrozole ${ }^{11}$ as non-steroid specific aromatase inhibitors (AIs) can efficiently decrease the recurrence rate of hormone-dependent breast cancer. Exemestane is a mechanism-based inhibitor and inhibits aromatase in an irreversible manner ${ }^{12}$, but other AIs like letrozole and anastrozole act as competitive and reversible inhibitors. But their mechanism of action still remain unclear. ${ }^{13,14}$ Until today, non-steroidal aromatase inhibitors (NSAIs) are the most progressive kinds ${ }^{15}$ but these are related with few side-effects. This motivates to take a new challenge for development of a new generation of AIs based on natural compounds and their derivatives such as coumarin, lignin and flavonoids. ${ }^{16}$ It is approved that with the structural modification of isoflavanone through various approaches, a new derivative has been developed having greater ability to inhibit the aromatase activity. ${ }^{17}$

Upon extensive literature review of $C$. sativa as medicine, it is seen that endo-cannabinoids can act as selective inhibitors of human breast cancer cell proliferation through a growth factor-dependent mechanism. $^{18,19}$ It has been reported that cannabinoids can act through different cellular mechanisms by inducing apoptosis, cell-cycle arrest, or cell growth inhibition, targeting angiogenesis and cell migration. ${ }^{20-22}$ In-silico screening techniques from the compound databases is presently the most popular and useful cheminformatics application in the field of drug discovery. In the current approach, the cannabinoids from the plant, $C$. sativa as a source of a lead molecule, was used for development of an aromatase inhibitor via computer based analytical techniques using ligand-based molecular docking, drug-like property analysis and ADMET prediction studies and we, here in, report the results of our in silico and laboratory-based studies.

\section{MATERIALS AND METHODS}

Data retreival of molecular modeling studies. The crystal structure of human placental aromatase cytochrome $\mathrm{P} 450$ in complex with androstenedione (PDB:3EQM) ${ }^{23}$ has been retrieved from the RCSB protein data bank (http://www.pdb.org). The enzyme is co-crystallized with androstenedione, protoporphirin IX containing $\mathrm{Fe}^{+3}$ and phosphate ion. Structure-based modeling study was performed with this crystallographic receptor (Figure 1) as clues for catalytic site grid generation in molecular docking.

Molecular docking of cannabinoids against aromatase. The molecular docking has great promise in virtual lead discovery as the scoring algorithms become more refined along with the continuous improvement in computer processing power and capabilities. ${ }^{24}$ In the present study, dataset containing 61 cannabinoid compounds ${ }^{25-27}$ designated as $\mathrm{CN}$ (Table 1) were docked at the binding site of aromatase protein 3EQM. The protein structure was prepared by Protein Preparation Wizard, in tool of Schrödinger, Inc. ${ }^{28,29}$ All ligands in dataset were prepared in Ligprep tool (Ligprep 2013), Version 2.8, Schrodinger, LLC, New York). ${ }^{30}$ Epik based ionization was used to generate all possible ionization states of the ligands in $\mathrm{pH}$ range of $7.0 \pm 0.5$ (Figure 2). These prepared molecules were subsequently docked at the active site of (PDB:3EQM) by standard precision (SP) mode in Glide (Figure 3). The best docked pose of each ligand was selected on the basis of the highest dock score. 
Table 1. Docking score of the compound in the dataset. ${ }^{25-27}$

\begin{tabular}{|c|c|c|c|c|c|}
\hline $\begin{array}{l}\text { Sl. } \\
\text { No. }\end{array}$ & $\begin{array}{l}\text { Compound } \\
\text { ID }\end{array}$ & Compound name & $\begin{array}{l}\text { Docking } \\
\text { score }\end{array}$ & $\begin{array}{l}\text { Bonding } \\
\text { interaction }\end{array}$ & Hydrophobic interaction \\
\hline 1 & CN1 & $\begin{array}{l}\text { Cannabigerolic acid } \\
\text { (CBGA) }\end{array}$ & -5.62 & HEM600 & $\begin{array}{l}\text { Val370, Phe221, Val369, Val313, Ile305, Ala306, Leu372, } \\
\text { Val373, Met374, Phe134, Ile133, Trp224, Leu477 }\end{array}$ \\
\hline 2 & $\mathrm{CN} 2$ & $\begin{array}{l}\text { Cannabigerolic acid } \\
\text { monomethylether ( } \\
\text { CBGAM) }\end{array}$ & -4.41 & $\begin{array}{l}\text { ARG115, } \\
\text { MET374 }\end{array}$ & $\begin{array}{l}\text { Val373, Phe134, Ile133, Ile305, Ala306, Phe221, Trp224, } \\
\text { Val370, Leu372, Leu477 }\end{array}$ \\
\hline 3 & $\mathrm{CN} 3$ & Cannabigerol (CBG) & -6.62 & HEM600 & $\begin{array}{l}\text { Val373, Leu372, Met374, Leu477, Trp224, Phe134, } \\
\text { Val369, Ile133, Phe221, Ile305, Ala306, Met127, Val370, } \\
\text { Val373, Leu372 }\end{array}$ \\
\hline 4 & $\mathrm{CN} 4$ & $\begin{array}{l}\text { Cannabigerol } \\
\text { monomethylether } \\
\text { (CBGM) }\end{array}$ & - & - & - \\
\hline 5 & CN5 & Cannabigerovarin & -8.34 & ARG115 & $\begin{array}{l}\text { Ile133, Ala303, Ile305, Trp224, Phe221, Val369, Leu479, } \\
\text { Val370, Leu447, Leu372 }\end{array}$ \\
\hline 6 & CN6 & $\begin{array}{l}\text { Cannabigerovarin } \\
(\mathrm{CBGV})\end{array}$ & -7.8 & HEM600 & $\begin{array}{l}\text { Val370, Leu372, Met374, Phe134, Ile133, Ala306, Ile305, } \\
\text { Phe221, Val373, Trp224, Leu477 }\end{array}$ \\
\hline 7 & $\mathrm{CN} 7$ & $\begin{array}{l}\text { Cannabichromenic acid } \\
\text { (CBCA) }\end{array}$ & -7.73 & HEM600 & $\begin{array}{l}\text { Ile70, Met374, Leu372, Leu477, Val373, Ile133, Ile305, } \\
\text { Val370, Ala306, Val369, Phe221, Val313, Trp224, Phe134 }\end{array}$ \\
\hline 8 & $\mathrm{CN} 8$ & $\begin{array}{l}\text { Cannabichromene } \\
\text { (CBC) }\end{array}$ & - & - & - \\
\hline 9 & $\mathrm{CN} 9$ & $\begin{array}{l}\text { Cannabichromevarinic } \\
\text { acid (CBCVA) }\end{array}$ & -7.45 & HEM600 & $\begin{array}{l}\text { Leu372, Met374, Phe134, Val373, Ile133, Ile305, Ala306, } \\
\text { Trp224, Phe221, Val369, Val307, Leu477 }\end{array}$ \\
\hline 10 & $\mathrm{CN} 10$ & $\begin{array}{l}\text { Cannabichromevarin } \\
(\mathrm{CBCV})\end{array}$ & -8.29 & HEM600 & $\begin{array}{l}\text { Val370, Leu372, Leu477, Phe134, Val373, Met127, Ile305, } \\
\text { Ala306, Ile133, Phe221, Trp224 }\end{array}$ \\
\hline 11 & CN11 & $\begin{array}{l}\text { Cannabidiolic acid } \\
\text { (CBDA) }\end{array}$ & - & - & - \\
\hline 12 & $\mathrm{CN} 12$ & Cannabidiol (CBD) & -5.98 & HEM600 & $\begin{array}{l}\text { Met374, Leu372, Trp224, Phe134, Ile133, Ile305, Ala306, } \\
\text { Phe221, Val370, Val373, Leu477 }\end{array}$ \\
\hline 13 & $\mathrm{CN} 13$ & $\begin{array}{l}\text { Cannabidiol } \\
\text { monomethylether } \\
\text { (CBDM) }\end{array}$ & - & - & - \\
\hline 14 & $\mathrm{CN} 14$ & $\begin{array}{l}\text { Cannabidiol-C4 (CBD- } \\
\text { C4) }\end{array}$ & -6.84 & $\begin{array}{l}\text { HEM600, } \\
\text { ARG115 }\end{array}$ & $\begin{array}{l}\text { Val373, Met374, Phe134, Trp224, Ile133, Ala306, Ile305, } \\
\text { Phe221, Val369, Val370, Ile479, Leu372, Ile477 }\end{array}$ \\
\hline 15 & $\mathrm{CN} 15$ & $\begin{array}{l}\text { Cannabidivarinic acid } \\
\text { (CBDVA) }\end{array}$ & - & - & - \\
\hline 16 & CN16 & Cannabidivarin (CBDV) & -8.34 & HEM600 & $\begin{array}{l}\text { Val373, Met374, Trp224, Phe134, Ile133, Ilke305, Phe221, } \\
\text { Val369, Val370, Leu372, Leu477 }\end{array}$ \\
\hline 17 & $\mathrm{CN} 17$ & $\begin{array}{l}\text { Cannabidiorcol (CBD- } \\
\text { C1) }\end{array}$ & -9.03 & HEM600 & $\begin{array}{l}\text { Val373, Met374, Trp224, Phe134, Ile133, Ile305, Ala306, } \\
\text { Phe221, Val369, Val370, Leu372, Leu477 }\end{array}$ \\
\hline 18 & $\mathrm{CN} 18$ & $\begin{array}{l}\text { Delta-9-tetrahydro- } \\
\text { cannabinolic acid A } \\
\text { (THCA-A) }\end{array}$ & 3.27 & $\begin{array}{l}\text { H-Bond } \\
\text { with } \\
\text { MET374, } \\
\text { П-П } \\
\text { interaction } \\
\text { with } \\
\text { PHE134 }\end{array}$ & $\begin{array}{l}\text { Val373, Met374, Trp224, Ile133, Ile305, Ala306, Phe221, } \\
\text { Val369, Val370, Leu372, Leu477 }\end{array}$ \\
\hline 19 & CN19 & $\begin{array}{l}\text { Delta-9-tetrahydro- } \\
\text { cannabinolic acid B } \\
\text { (THCA-B) }\end{array}$ & - & - & - \\
\hline 20 & $\mathrm{CN} 20$ & $\begin{array}{l}\text { Delta-9-tetrahydro- } \\
\text { cannabinol (THC) }\end{array}$ & - & - & - \\
\hline 21 & $\mathrm{CN} 21$ & $\begin{array}{l}\text { Delta-9- } \\
\text { tetrahydrocannabinol-C4 } \\
\text { (THC-C4) }\end{array}$ & - & - & - \\
\hline 22 & $\mathrm{CN} 22$ & $\begin{array}{l}\text { Delta-9- } \\
\text { tetrahydrocannabi- } \\
\text { varinic acid (THCVA) }\end{array}$ & -4.16 & $\begin{array}{l}\text { MET374, } \\
\text { PHE134 } \\
\text { П-П } \\
\text { Interaction }\end{array}$ & $\begin{array}{l}\text { Ile70, Val373, Met374, Trp224, Ile133, Ile305, Ala306, } \\
\text { Phe221, Val369, Val370, Leu372, Leu477 }\end{array}$ \\
\hline
\end{tabular}


Table 1 Contd.

\begin{tabular}{|c|c|c|c|c|c|}
\hline 23 & $\mathrm{CN} 23$ & $\begin{array}{l}\text { Delta-9-tetrahydrocanna- } \\
\text { bivarin (THCV) }\end{array}$ & - & - & - \\
\hline 24 & $\mathrm{CN} 24$ & $\begin{array}{l}\text { Delta-9-tetrahydrocanna- } \\
\text { biorcol (THC-C1) }\end{array}$ & - & - & - \\
\hline 25 & $\mathrm{CN} 25$ & $\begin{array}{l}\text { Delta-7-cis-iso- } \\
\text { tetrahydro-cannabivarin }\end{array}$ & - & - & - \\
\hline 26 & $\mathrm{CN} 26$ & $\begin{array}{l}\text { Delta-8-tetrahydrocanna- } \\
\text { binolic acid (delta8- } \\
\text { THCA) }\end{array}$ & - & - & - \\
\hline 27 & $\mathrm{CN} 27$ & $\begin{array}{l}\text { Delta-8- } \\
\text { tetrahydrocannabinol } \\
\text { (delta8-THC) }\end{array}$ & - & - & - \\
\hline 28 & $\mathrm{CN} 28$ & $\begin{array}{l}\text { Cannabicyclolic acid } \\
\text { (CBLA) }\end{array}$ & - & - & - \\
\hline 29 & $\mathrm{CN} 29$ & Cannabicyclol (CBL) & - & - & - \\
\hline 30 & $\mathrm{CN} 30$ & $\begin{array}{l}\text { Cannabicyclovarin } \\
(\mathrm{CBLV})\end{array}$ & - & & - \\
\hline 31 & $\mathrm{CN} 31$ & $\begin{array}{l}\text { Cannabielsoic acid A } \\
\text { (CBEA-A) }\end{array}$ & - & - & - \\
\hline 32 & $\mathrm{CN} 32$ & $\begin{array}{l}\text { Cannabielsoic acid B } \\
\text { (CBEA-B) }\end{array}$ & - & - & - \\
\hline 33 & $\mathrm{CN} 33$ & Cannabielsoin (CBE) & - & - & - \\
\hline 34 & $\mathrm{CN} 34$ & $\begin{array}{l}\text { Cannabinolic acid } \\
\text { (CBNA) }\end{array}$ & - & - & - \\
\hline 35 & $\mathrm{CN} 35$ & Cannabinol (CBN) & - & - & - \\
\hline 36 & $\mathrm{CN} 36$ & $\begin{array}{l}\text { Cannabinol } \\
\text { methylether(CBNM) }\end{array}$ & - & - & - \\
\hline 37 & $\mathrm{CN} 37$ & $\begin{array}{l}\text { Cannabinol-C4 (CBN- } \\
\text { C4) }\end{array}$ & - & - & - \\
\hline 38 & CN38 & Cannabivarin (CBV) & & - & - \\
\hline 39 & CN39 & $\begin{array}{l}\text { Cannabinol-C2 (CBN- } \\
\text { C2) }\end{array}$ & -3.93 & LEU477 & $\begin{array}{l}\text { Val373, Met374, Trp224, Phe134, Ile133, Ala306, Phe221, } \\
\text { Val369, Val370, Leu372 }\end{array}$ \\
\hline 40 & $\mathrm{CN} 40$ & Cannabiorcol (CBN-C1) & - & - & - \\
\hline 41 & $\mathrm{CN} 41$ & Cannabinodiol (CBND) & -6.14 & HEM600 & $\begin{array}{l}\text { Val373, Met374, Met127, Trp224, Phe134, Ile133, Ile305, } \\
\text { Ala306, Phe221, Val369, Val370, Leu372, Leu379, } \\
\text { Leu477 }\end{array}$ \\
\hline 42 & $\mathrm{CN} 42$ & $\begin{array}{l}\text { Cannabinodivarin } \\
\text { (CB VD) }\end{array}$ & -6.59 & HEM600 & $\begin{array}{l}\text { Val373, Met374, Trp224, Phe134, Ile133, Ile305, Ala306, } \\
\text { Ala307, Phe221, Val369, Val370, Leu372, Leu477 }\end{array}$ \\
\hline 43 & $\mathrm{CN} 43$ & Cannabitriol (CBT) & -7.86 & ALA306 & $\begin{array}{l}\text { Val373, Met374, Trp224, Phe134, Ile133, Ile305, Phe221, } \\
\text { Val369, Val370, Leu372, Leu477 }\end{array}$ \\
\hline 44 & $\mathrm{CN} 44$ & $\begin{array}{l}\text { 10-Ethoxy-9-hydroxy- } \\
\text { delta-6a- } \\
\text { tetrahydrocannabinol }\end{array}$ & - & - & - \\
\hline 45 & CN45 & $\begin{array}{l}\text { 8,9-Dihydroxy-delta-6a- } \\
\text { tetrahydrocannabinol }\end{array}$ & - & - & - \\
\hline 46 & $\mathrm{CN} 46$ & $\begin{array}{l}\text { Cannabitriolvarin } \\
\text { (CBTV) }\end{array}$ & - & - & - \\
\hline 47 & $\mathrm{CN} 47$ & $\begin{array}{l}\text { Ethoxycannabitriolvarin } \\
\text { (CBTVE) }\end{array}$ & - & - & - \\
\hline 48 & $\mathrm{CN} 48$ & $\begin{array}{l}\text { Dehydrocannabifuran } \\
\text { (DCBF) }\end{array}$ & - & - & - \\
\hline 49 & $\mathrm{CN} 49$ & Cannabifuran (CBF) & - & - & - \\
\hline 50 & CN50 & $\begin{array}{l}\text { Cannabichromanon } \\
(\mathrm{CBCN})\end{array}$ & - & - & - \\
\hline 51 & CN51 & Cannabicitran (CBT) & - & - & - \\
\hline 52 & CN52 & $\begin{array}{l}\text { 10-Oxo-delta-6a- } \\
\text { tetrahydrocannabinol } \\
\text { (OTHC) }\end{array}$ & - & - & - \\
\hline
\end{tabular}


Table 1 Contd.

\begin{tabular}{|c|c|c|c|c|c|}
\hline 53 & CN53 & $\begin{array}{l}\text { Delta-9-cis-tetrahydro- } \\
\text { cannabinol (cis-THC) }\end{array}$ & -7.43 & LEU477 & $\begin{array}{l}\text { Val373, Met374, Trp224, Phe134, Ile133, Phe221, Val369, } \\
\text { Val370, Leu372, Leu479. }\end{array}$ \\
\hline 54 & CN54 & $\begin{array}{l}\text { 3,4,5,6-Tetrahydro-7- } \\
\text { hydroxy-alpha-alpha-2- } \\
\text { trimethyl-9-n-propyl- } \\
\text { 2,6-methano-2H-1- } \\
\text { benzoxocin-5-methanol } \\
\text { (OH-iso-HHCV) }\end{array}$ & -5.02 & LEU477 & $\begin{array}{l}\text { Val373, Met374, Trp224, Phe134, Ile133, Ile305, } \\
\text { Ala307,Ala306, Phe221, Val369, Val370, Leu372 }\end{array}$ \\
\hline 55 & CN55 & Cannabiripsol(CBR) & -6.93 & HEM600 & $\begin{array}{l}\text { Val373, Met374, Trp224, Phe134, Ile133, Ile305, Ala306, } \\
\text { Ala307, Phe221, Val369, Val370, Leu372, Leu477 }\end{array}$ \\
\hline 56 & CN56 & $\begin{array}{l}\text { Trihydroxy-delta-9-tetra- } \\
\text { hydrocannabinol (triOH- } \\
\text { THC) }\end{array}$ & - & - & - \\
\hline 57 & CN57 & $\begin{array}{l}\text { Delta-9-tetrahydrocanna- } \\
\text { binolic acid-C4-A } \\
\text { (THCA-C4-A) }\end{array}$ & -4.18 & $\begin{array}{l}\text { MET374, } \\
\text { PHE134 } \\
\Pi-\Pi \\
\text { interaction }\end{array}$ & $\begin{array}{l}\text { Val373, Trp224, Phe134, Ile133, Ile305, Ala306, Phe221, } \\
\text { Val369, Val370, Leu372, Leu477 }\end{array}$ \\
\hline 58 & CN58 & $\begin{array}{l}\text { Delta-9-tetrahydrocanna- } \\
\text { binolic acid-C4-B } \\
\text { (THCA-C4-B) }\end{array}$ & - & - & - \\
\hline 59 & CN59 & $\begin{array}{l}\text { Delta-9- } \\
\text { tetrahydrocannabi- } \\
\text { orcolic acid-A (THCA- } \\
\text { C1-A) }\end{array}$ & - & - & - \\
\hline 60 & CN60 & $\begin{array}{l}\text { Delta-9-tetrahydrocanna- } \\
\text { biorcolic acid-B (THCA- } \\
\text { C1-B) }\end{array}$ & - & - & - \\
\hline 61 & CN61 & Nabilone & - & - & - \\
\hline 62 & AR1 & Androstenedione & -6.67 & $\begin{array}{l}\text { МЕT374, } \\
\Pi-\Pi \\
\text { interaction } \\
\text { TRP224 }\end{array}$ & $\begin{array}{l}\text { Val373, Trp224, Phe134, Ile133, Ile305, Ala306, Phe221, } \\
\text { Val369, Val370, Leu372, Leu477 }\end{array}$ \\
\hline 63 & AR2 & Fadrozole & -3.06 & $\begin{array}{l}\text { MET374, } \\
\Pi-\Pi \\
\text { interaction } \\
\text { TRP224 }\end{array}$ & $\begin{array}{l}\text { Val373, Met374, Trp224, Phe134, Ile133, Ile305, Ala306, } \\
\text { Phe221, Val369, Val370, Leu372, Leu477 }\end{array}$ \\
\hline
\end{tabular}

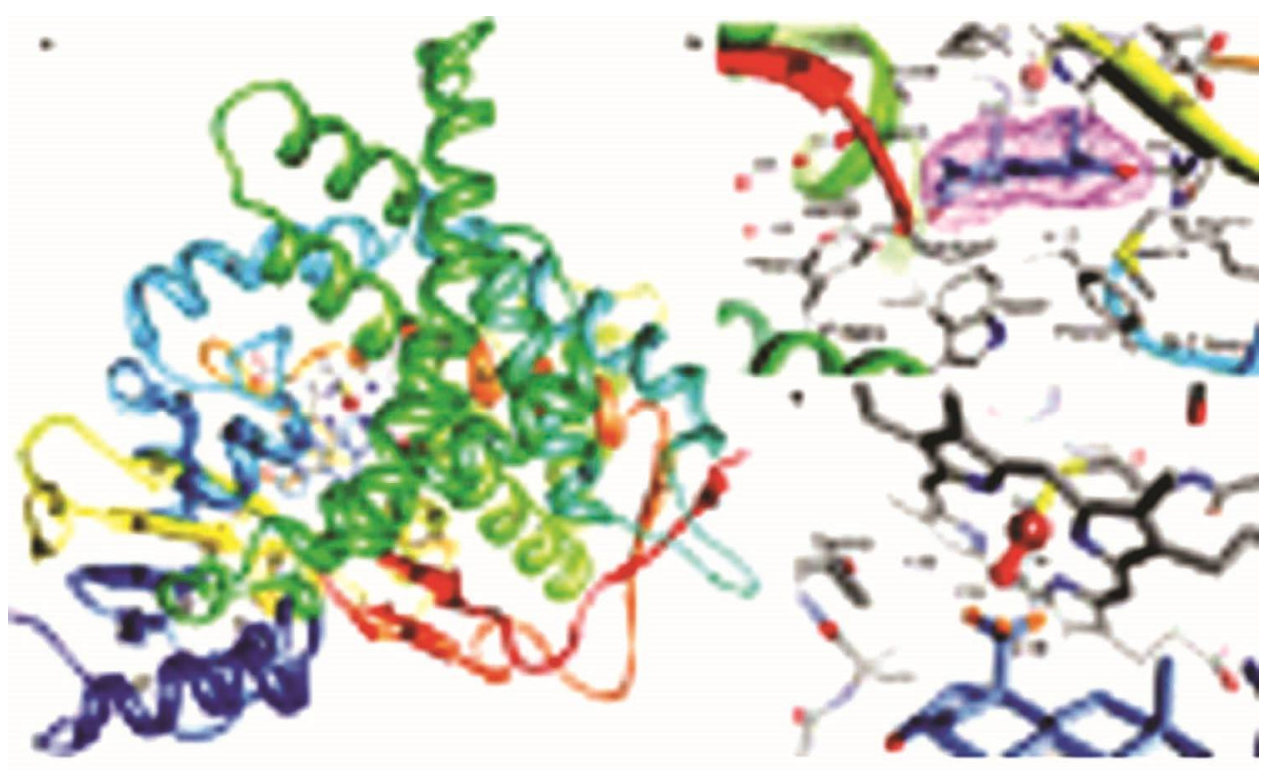

Figure 1. Structure of the PDB:3EQM protein. 


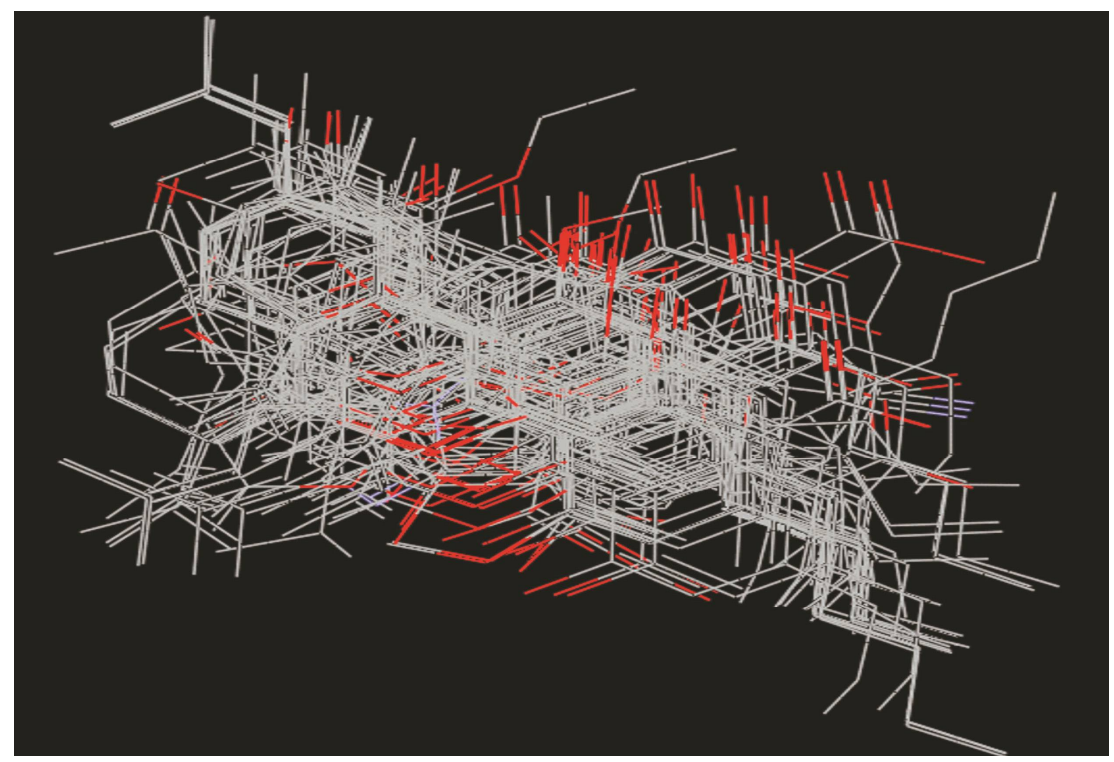

Figure 2. Ionized Ligands (Cannabinoids and standard) prepared for docking (displayed in line style) (ashcarbon, red- oxygen, blue-nitrogen; hydrogen- not shown).
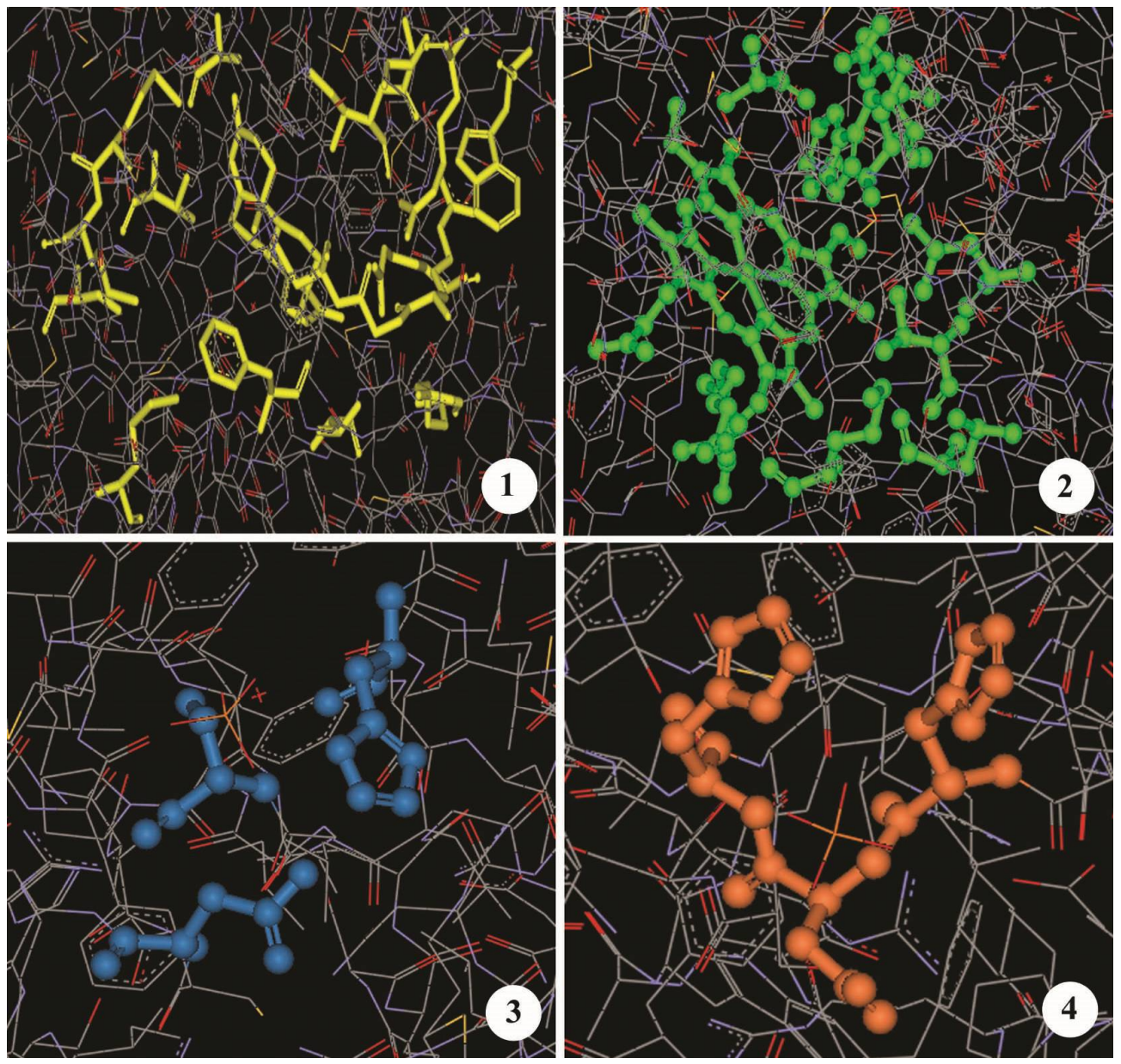

Figure 3. Zone of active sites of the aromatase enzyme docked with molecules. (Yellow-Active site 1 (HEM), GreenActive site 2 (HEM), Blue- Active site 3, two PO4, Orange- Active site 4, co-crystal ligand). 
Drug-likeness and pharmacokinetic prediction (ADMET) analysis. In drug discovery technique, the concept of greater drug-likeliness was used for post virtual screening of a chemical database. The in silico approach consists of a physicochemical filters like Lipinski's rule of five $\mathrm{e}^{31}$ or pharmacokinetic filters like absorption, distribution, metabolism and excretion and toxicity (ADMET) property were applied to select drug-like compounds. ${ }^{32}$ Promising drug candidates often fail due to unfavorable ADMET properties. Computational QSAR models for predicting ADMET properties were used for prediction of ADMET parameters. ${ }^{33}$ Before selecting the hit compounds, the ADMET properties of compounds were predicted using the QikProp 3.9 module $^{34}$ to check molecular weight, $\log$ Po/w, logHERG (potential hERG channel blockage leads to QT syndrome), and human oral absorption of the compounds.

Collection of plant sample and extraction. The plant material, Cannabis sativa (FamilyCannabaceae) was collected with the help of Department of Narcotics Control, Government of the Peoples's Republic of Bangladesh after getting proior permission. According to th Department of Narcotics Control, the sample was collected from Kushtia district, Bangladesh. The weight of the dried sample when received, was 550 gram. The sample was verified by the National Herbarium of Bangladesh with an accession number (DACB 38696).

The dried sample was then grinded into powder and sieved to yield a finer grade. Then it was weighed, divided into three portions and packed for extraction. Soxhlet apparatus ${ }^{35}$, a very solvent efficient way of extraction by recycling a small amount of solvent, was used for the extraction. On the basis of the solubility of the target compounds, ethanol was used and 10 cycles were run for three portions and combined. The non-soluble portion of the extracted solid remaining in the thimble was dried and returned to the Department of Narcotics Control as per the terms and condition.

The alcoholic soluble extract was dried over baked magnesium sulfate and subjected to rotary evaporation. After solvent evaporation, a gummy mass of about 40 gram was obtained. The gummy material was transferred to Claisen distillation flask for fractional distillation. A good number of oily fractions were obtained at different temperature and subjected for mass spectroscopic studies regarding molecular indentification of the target compounds.

Cytotoxicity assay of the fractionated compounds. The bioactivity of the fractionated compounds was evaluated by the brine shrimp lethality test. ${ }^{36}$ Eleven washed and numbered test tubes were taken for each sample. Two mg of each fraction was weighed and dissolved in $1000 \mu \mathrm{l}$ dimethyl sulfoxide (DMSO). Then $800 \mu$ lof the dissolved fractions were put inside the first test tube making $1000 \mu \mathrm{l}$. From this, $500 \mu \mathrm{l}$ was transfer to second tube and made the solution $10 \mathrm{~mL}$ giving a concentration of $40 \mu \mathrm{g} / \mathrm{ml}$ in first tube. The transfered $500 \mu \mathrm{l}$ was made $1000 \mu \mathrm{l}$ in second test tube by adding DMSO. Then again $500 \mu \mathrm{l}$ from the second was taken to third test tube and giving a concentration of $20 \mu \mathrm{g} / \mathrm{ml}$ in second test tube. The same process was repeated for all the test tubes and the $11^{\text {th }}$ one was left blank with only DMSO in it. Then, 10 brine shrimp lervae were counted and put into each of them and the final volume was adjusted to $10 \mathrm{~mL}$ by adding artificial sea saltwater. Thus, the concentrations of the fractionated compounds were 40-, 20-, 10-, 5-, 2.5-, 1.25-, 0.625-, 0.3125-, 0.1563and $0.0781 \mu \mathrm{g} / \mathrm{ml}$.

Then the test tubes were incubated at room temperature for $24 \mathrm{hrs}$. The tubes were then examined under a magnifying glass and the number of dead nauplii in each tube counted. Vincristine sulfate was used as a positive control in all experiments. The concentration of vincristine sulfate was same as that of test samples. Experiments were conducted for 3 times and the average values were used to determine the $\mathrm{LC}_{50}$ value for each of the fraction.

Statistics. The experimental results of the brine shrimp lethality assay were expressed as the mean value $\pm \mathrm{SD}(\mathrm{n}=3)$. The one-way ANOVA test was performed to determine the significant mean 
difference $(n=3)$ between the samples followed by Tukey's multiple comparisons test by using graph pad prism 6.0.

\section{RESULTS AND DISCUSSION}

Molecular docking study. Docking score and catalytic interactions (Ala306, Val370, Leu372, Val373, Met374, Leu377, Leu477 and Hem600) were observed and compared between ligand compounds and receptors and the standard drugs fadrozole (AR1) and androstenedione (AR2). All the compounds (high and low activity) formed at least one hydrogen bond with Met 374. But the difference in the inhibitory activity between different compounds dependend on the steric clashes of the compounds in the active site with important aminoacid residues as well as most importantly with the iron atom of the heme moiety. Apart from the hydrogen bond formation with the oxygen present on the aromatic ring system, other parts of the molecules were stabilized by hydrophobic interactions with the non-polar amino acids (Ala306, Trp224, Val369, Val370, Ile133, Phe134). This is in agreement with previous observations with non-steroidal aromatase inhibitors. $^{37}$

Molecular docking has the potential to predict accurate binding affinities of screening hits as well as potentially reveal lead structures with novel modes of binding interaction. ${ }^{23}$ After docking all dataset ligands along with two standard drug, fadrozole (AR1) and androstenedione (AR2), docking scores were obtained which represents their 'affinity' or 'potententiality' for binding aromatase. Out of 61 cannabinoids, 21 compounds (CN1, CN2, CN3, CN5, CN6, CN7, CN9, CN10, CN12, CN14, CN16, CN17, CN22, CN39, CN41, CN42, CN43, CN53, CN54, CN55 and CN57) showed a very close score to standard aromatase inhibitor (AR1 and AR2). The clustered column chart of their docking scores (Table 1) is shown in Figure 4.

Finally it is seen that only14 compounds have docked score greater than 6 which are more nearer with the AR1 compound. Upon analysis of the docking results, it was seen that compounds which bound with the heme showed a good docking score, and their hydrophobic interaction was similar to the standard compound. The only difference is that there was no interaction with the heme in case of the standard compounds (AR1 and AR2). It is reported that the hydrophobic residues and porphyrin rings of haem pack tightly, forming a cavity in shape to the bound steroid, androstenedione (AR2). But it is established that close interaction with the haem $\mathrm{Fe}^{+3}$ (3.42 $\AA$ ) in the active site of the enzyme is very much essential requirement for the aromatase inhibition. ${ }^{35}$ Similarly, the researcehers proved the importance of molecular hydrophobicity for inhibition of aromatase enzyme. ${ }^{38}$ It is seemed that compounds that bind with the heme showed better anticancer property than

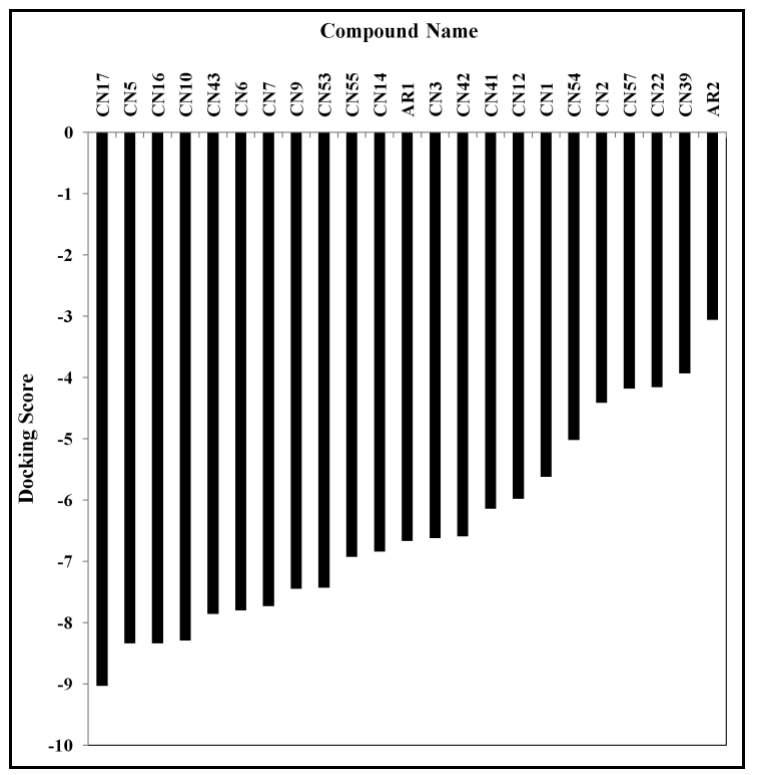

Figure 4. Clustered column chart indicating the docking scores of 21 cannabinoids (CNs) and standards (AR1 and AR2).

others. It is due to the fact that after binding to the heme, the oxygen carrying capacity of the heme will be reduced, which causes the cell death that is the only purpose of the anticancer drugs. So, this docking analysis with their interaction between receptor and ligand molecules approved the previous study.

Drug-likeness and ADMET study. Finally, all 14 compounds were checked for their drug-likeness through the Lipinski filter rule and only the 3 compounds such as cannabidiorcol (CN 17, CBD- 
C1), cannabitriol (CN 43, CBT) and cannabiripsol (CN 55, CBR) (Figure 5) had been passed (Table 2) and then they were used for further ADMET test by Qikprop.

ADMET analysis ${ }^{34}$, which yielded 3 active hit molecules, showed the all the acceptable pharmacokinetic parameters, such as molecular weight, $\log \mathrm{Po} / \mathrm{w}, \quad \operatorname{logHERG}$ and human oral absorption, which are essential for drug-likeness prediction, are shown in Table 3. The binding interaction of the promising molecules are represented in Figure 6.

Table 2. Analysis of drug-like property.

\begin{tabular}{llll}
\hline \multicolumn{2}{c}{ Drug-like } & Failed compounds & \\
\hline CN17 & Passed & CN3 & Lipinski Failure: partition coefficient $>5$ \\
CN43 & Passed & CN5 & Lipinski Failure: partition coefficient $>5$ \\
CN55 & Passed & CN6 & Lipinski Failure: partition coefficient $>5$ \\
AR1 & Passed & CN7 & Lipinski Failure: partition coefficient $>5$ \\
AR2 & Passed & CN9 & Lipinski Failure: partition coefficient $>5$ \\
& & CN10 & Lipinski Failure: partition coefficient $>5$ \\
& & CN14 & Lipinski Failure: partition coefficient $>5$ \\
& & LN16 & Lipinski Failure: partition coefficient $>5$ \\
& & CN41 & Lipinski Failure: partition coefficient $>5$ \\
& & CN42 & Lipinski Failure: partition coefficient $>5$ \\
\hline
\end{tabular}

Table 3. The ADMET profiles of the promising compounds.

\begin{tabular}{ccccccc}
\hline Hit molecule & Mol_MW $^{\mathrm{a}}$ & $\operatorname{logPo} / \mathrm{w}^{\mathrm{b}}$ & $\operatorname{logHERG}^{\mathrm{c}}$ & PCaco $^{\mathrm{d}}$ & \%HumanOralAbsorption $^{\mathrm{e}}$ & RuleOfFive $^{\mathrm{f}}$ \\
\hline CN43 & 346.47 & 3.95 & -4.74 & 1384.19 & 100 & 0 \\
CN17 & 258.36 & 3.85 & -4.17 & 3062.65 & 100 & 0 \\
CN55 & 348.48 & 3.93 & -4.71 & 1131.26 & 100 & 0 \\
\hline
\end{tabular}

${ }^{\mathrm{a}}$ Molecular weight (acceptable range <500). ${ }^{\mathrm{b}}$ Predicted octanol/water partition coefficient log p (acceptable range from -2.0 to 6.5). ${ }^{\mathrm{c}}$ Predicted value for blockage of HERG K+ channels (concern below -6.5$)$. ${ }^{\mathrm{d}}$ Predicted Caco-2 cell permeability in nm/s (acceptable range: $<25$ is poor and $>500$ is great). ${ }^{\mathrm{e}}$ Percentage of human oral absorption ( $<25 \%$ is poor and $>80 \%$ is high). ${ }^{\mathrm{f}}$ Rule of five (no. of violations of Lipinski's rule of five: 0 is good and 4 is bad).

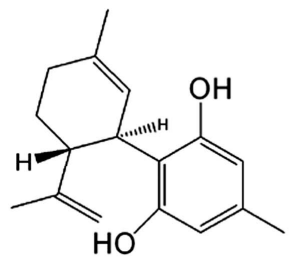

CBD-C1

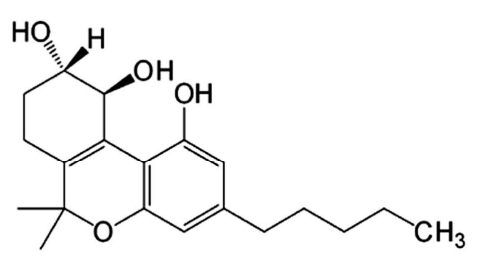

CBT

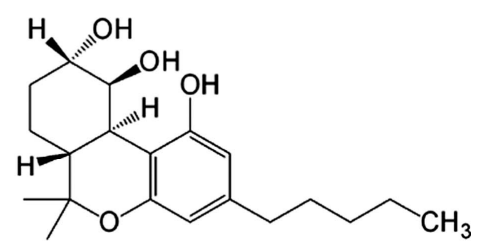

CBR

Figure 5. Structures of cannabidiorcol (CBD-C1), cannabitriol (CBT) and cannabiripsol (CBR).

The target compounds are cannabidiorcol $(\mathrm{CN}$ 17), cannabitriol (CN 43) and cannabiripsol (CN 55). C. sativa was collected from Department of Narcotics Control as mentined earlier. The dried sample was extracted with ethanol in a Soxhlet apparatus. The alcoholic portion (extract) was dried over baked magnesium sulfate and evaporate to dryness. The gummy crude mass obtained after evaporation of solvent was transferred to Claisen distillation flask for fractional distillation. A number of oily fractions were obtained at different temperature and subjected for mass spectroscopic analysis. The spectrometey 
was employed to analyze the precursor ions under investigation. The ions were indetified as cannabidiorcol (CN 17), cannabitriol ( $\mathbf{C N ~ 4 3 )}$ and cannabiripsol (CN 55) with $\mathrm{m} / \mathrm{z}$ values $259.352,347$. 485 and 349.365, respectively for the corresponding pseudomolecular ion as $[\mathrm{M}+\mathrm{H}]^{+}$.

Cytotoxicity assay of the target compounds. The cytotoxicity of cannabidiorcol (CN 17), cannabitriol (CN 43) and cannabiripsol (CN 55) were evaluated trough brine shrimp lethality bioassay technique where vincristine sulfate was used as positive control. Cannabidiorcol exhibited $\mathrm{LC}_{50}$ value of $0.348 \pm 0.002 \mu \mathrm{g} / \mathrm{ml}\left(\mathrm{R}^{2}=0.985\right)$ which is almost similar to vincristine sulfate $\left(\mathrm{LC}_{50}=0.316 \pm 0.003\right.$ $\mu \mathrm{g} / \mathrm{ml}, \mathrm{R}^{2}=0.988$ ), whereas cannabitriol also showed promisimg cytotoxicity with $\mathrm{LC}_{50}$ of $0.650 \pm 0.004$ $\mu \mathrm{g} / \mathrm{ml}\left(\mathrm{R}^{2}=0.988\right)$ in comparison to reference standard. However, cannabiripsol exhibited relatively weaker activity with $\mathrm{LC}_{50}$ of $12.95 \pm 1.234 \mu \mathrm{g} / \mathrm{ml}\left(\mathrm{R}^{2}\right.$ $=0.990)$ (Table 4).

\section{CN17 (Cannabidiorcol, CBD-C1)}

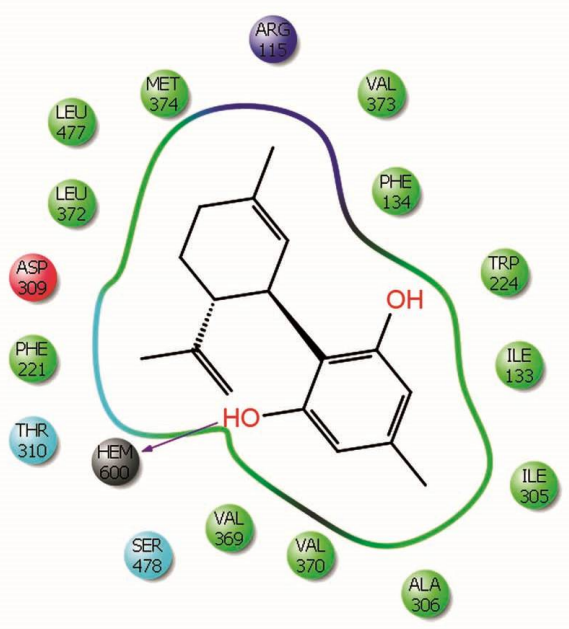

CN43 (Cannabitriol, CBT)

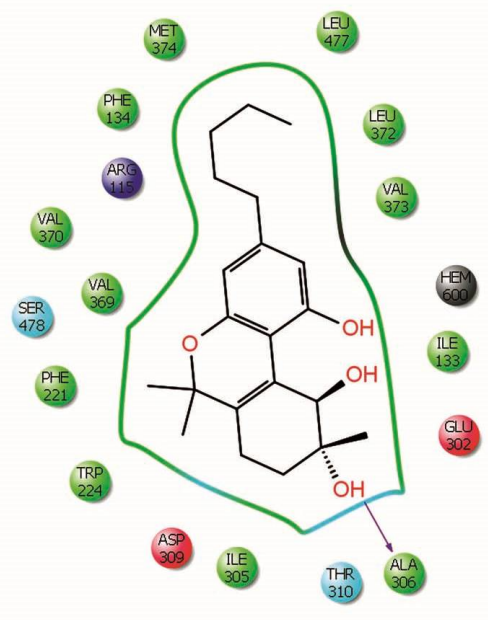

Figure 6. Binding interactions of the promising CN 17 ( Cannabidiorcol, CBD-C1) and CN 43 (Cannabitriol, CBT) molecules at the catalytic site.

Table 4. $\mathrm{LC}_{50}$ value of cannabidiorcol (CN 17), cannabitriol (CN 43) and cannabiripsol (CN 55) and standard from brine shrimp lethality bioassay.

\begin{tabular}{llll}
\hline Test samples & Regression line & $\mathrm{R}^{2}$ & $\begin{array}{l}\mathrm{LC}_{50}(\mu \mathrm{g} / \mathrm{ml}) \\
(\mathrm{Mean} \pm \mathrm{SD}\end{array}$ \\
\hline Cannabidiorcol & $\mathrm{y}=4.5389 \mathrm{x}+7.164$ & $\mathrm{R}^{2}=0.985$ & $0.348 \pm 0.002$ \\
Cannabitriol & $\mathrm{y}=36.003 \mathrm{x}+63.016$ & $\mathrm{R}^{2}=0.988$ & $0.650 \pm 0.004$ \\
Cannabiripsol & $\mathrm{y}=40.342 \mathrm{x}-2.112$ & $\mathrm{R}^{2}=0.990$ & $12.95 \pm 1.234$ \\
Vincristine sulphate & $\mathrm{y}=37.89 \mathrm{x}+68.695$ & $\mathrm{R}^{2}=0.988$ & $0.316 \pm 0.003$ \\
\hline
\end{tabular}

\section{CONCLUSION}

Breast cancer has become a life threatening disease to every human being in the recent years. In the present study, the selection of new cannabinoids as an anticancer drug through virtual screening technique and docking study helped us to explore some new molecules after their ADMET checking.
Finally, three molecules, cannabidiorcol, cannabitriol and cannabiripsol have been propsed as better candidates than the other. Subsequently, this has been evaluated in the laboratory by brine shrimp lethality assay and these three compounds have been proved to have significant cytotoxic activity. ${ }^{36,39}$ From this observation, it can be concluded that the lead 
compounds may be developed as potent aromatase inhibitors for performing their biological evaluation.

\section{ACKNOWLEDGEMENT}

One of the authors (SCB)) is grateful to the Ministry of Science, Information and Communication Technology, Govrernment of Bangladesh, sanction order 39.009.006.01.00.049.2013-2014/MEDE'S$25 / 637$ for financial support. The author AS is thankful to the University Grants Commission of Bangladesh for providing him support in SAARC fellowship in exchange program under the suppervison of SCB in the Department of Pharmacy, Faculty of Pharmacy, University of Dhaka.

\section{CONFLICT INTEREST}

There is no conflict of interest among the researchers who have contributed in this work.

\section{REFERENCES}

1. Hernandez, B.Y., Green, M.D., Cassel, K.D., Pobutsky, A.M., Vu, V. and Wilkens, L.R. 2010. Preview of Hawaii cancer facts and figures 2010. Hawaii Med. J. 69, 223-224.

2. Santen, R.J. and Harvey, H.A. 1999. Use of aromatase inhibitors in breast carcinoma. Endocr. Rel. Cancer 6, 75-92.

3. Bernstein, L., Deapen, D., Cerhan, J.R., Schwartz, S.M., Liff, J., McGann-Maloney, E., Perlman, J.A., and Ford, L. 1999. Tamoxifen therapy for breast cancer and endometrial cancer risk. J. Natl. Cancer Inst. 91,1654-1662.

4. Buzdar, A.U. 1999. Role of aromatase inhibitors in advanced breast cancer. Endocr. Rel. Cancer. 6, 219-225.

5. Santen, R.J., Yue, W., Naftolin, F., et al. 1999. The potential of aromatase inhibitors in breast cancer prevention. Endocr. Rel. Cancer 6, 235-243.

6. Chen, S. 1998. Aromatase and breast cancer. Front. Biosci. 3, 922-933.

7. Simpson, E.R., Mahendroo, M.S., Means, G.D., Kilgore, M.W., Hinshelwood, M.M., Graham- Lorence, S. et al. 1994. Aromatase cytochrome P450, the enzyme responsible for estrogen biosynthesis. Endocr. Rev. 15, 342-355.

8. Santen, R.J., Manni, A., Harvey, H. and Redmond, C. 1990. Endocrine treatment of breast cancer in women. Endocr Rev. 11, 221-265.

9. Coombes, R.C., Hall, E., Gibson, L.J., Paridaens, R., Jassem, J., Delozier, T., et al. 2004. A randomized trial of exemestane after two to three years of tamoxifen therapy in postmenopausal women with primary breast cancer. N. Engl. J. Med. 350,1081-1092.
10. Coates, A.S., Keshaviah, A., Thurlimann, B., Mouridsen, H., Mauriac, L., Forbes, J.F., et al. 2007. Five years of letrozole compared with tamoxifen as initial adjuvant therapy for postmenopausal women with endocrine- responsive early breast cancer: update of study BIG 1-98. J. Clin. Oncol. 25, 486-492.

11. Locker, G.Y., Mansel, R., Cella, D., Dobrez, D., Sorensen, S. and Gandhi, S.K. 2007. Cost-effectiveness analysis of anastrozole versus tamoxifen as primary adjuvant therapy for postmeno- pausal women with early breast cancer: a US healthcare system perspective. The 5-year completed treatment analysis of the ATAC ('Arimidex', Tamoxifen Alone or in Combination) trial. Breast Cancer Res. Treat. 106, 229-238.

12. Hong, Y., Yu, B., Sherman, M., Yuan, Y.C., Zhou, D. and Chen, S. 2007. Molecular basis for the aromatization reaction and exemestane- mediated irreversible inhibition of human aromatase. Mol. Endocrinol. 21, 401- 414.

13. Hong, Y., Rashid, R. and Chen, S. 2011. Binding features of steroidal and nonsteroidal inhibitors. Steroids 76, 802-806.

14. Kao, Y.C., Cam, L.L., Laughton, C.A., Zhou, D. and Chen, S. 1996. Binding characteristics of seven inhibitors of human aromatase: a site- directed mutagenesis study. Cancer Res. 56, 3451-3460.

15. Bhatnagar, A.S. 2007. The discovery and mechanism of action of letrozole. Breast Cancer Res. Treat. 105 (Suppl 1), 7-17.

16. Sakamoto, T., Horiguchi, H., Oguma, E. and Kayama, F. 2010. Effects of diverse dietary phytoestrogens on cell growth, cell cycle and apoptosis in estrogen-receptor-positive breast cancer cells. J. Nutr. Biochem. 21, 856-864.

17. Bonfield, K., Amato, E., Bankemper, T., Agard, H., Steller, J., Keeler, J.M., et al. 2012. Development of a new class of aromatase inhibitors: design, synthesis and inhibitory activity of 3-phenylchroman-4-one (isoflavanone) derivatives. Bioorg. Med. Chem. 20, 2603-2613.

18. Melck, D., De Petrocellis, L., Orlando, P., Bisogno, T., Laezza, C., Bifulco, M. and Di Marzo, V. 2000. Suppression of nerve growth factor Trk receptorand prolactin receptors by endocannabinoids leads to inhibition ofhuman breast and prostate cancer cell proliferation. Endocrinology 141, 118126.

19. De Petrocellis, L., Melck, D., Palmisano, A., Bisogno, T., Laezza, C., Bifulco, M. and Di Marzo, V. 1998. The endogenous cannabinoid anandamideinhibits human breast cancer cell proliferation. Proc. Natl. Acad. Sci. 95, 83758380 .

20. Bifulco, M. and Di Marzo, V. 2002. Targeting the endocannabinoid system in cancer therapy: a call for further research. Nat. Med. 8, 547-550.

21. Guzman, M. 2003. Cannabinoids: potential anticancer agents. Nat. Rev. Cancer 3, 745-755.

22. Kogan, N.M. 2005. Cannabinoids and cancer. Mini Rev. Med. Chem. 5, 941-952. 
23. Ghosh, D., Griswold, J., Erman, M. and Pangborn, W. 2009. Structural basis for androgen specificity and oestrogen synthesis in human aromatase. Nature 457 (7226), 219-23.

24. Prabhu, K., Mahto, M. K. and Gopalakrishnan, V. K. 2014. Virtual screening molecular docking and molecular dynamics studies for discovery of novel vegfr-2 inhibitors. Int. J. Pharm. Clin. Res. 6, 221-229.

25. ElSohly M.A. and Slade D. 2005. Chemical constituents of marijuana: The complex mixture of natural cannabinoids. Life Sci. 78, 539-548.

26. Turner C.E., ElSohly M.A. and Boeren E.G. 1980. Constituents of Cannabis sativa L. XVII. A review of the natural constituents. J. Nat. Prod. 43, 169-234.

27. Ross S.A. and ElSohly, M.A. 1995. Constituents of Cannabis sativa L. XXVIII. A review of the natural constituents: 19801994. Zagazig J. Pharmaceut. Sci. 4, 1-10.

28. Friesner, R. A., Banks, J. L., Murphy, R. B., Halgren, T. A., Klicic, J. J., Maint, D. T. and Shenkin, P. S. 2004. Glide: A new approach for rapid, accurate docking and scoring. 1. Method and assessment of docking accuracy. J. Med. Chem. 25, 1713-1749.

29. Halgren, T. A., Murphy, R. B., Friesner, R. A., Beard, H. S., Frye, L. L., Pollard, W. T. and Banks, J. L. 2004. Glide: A new approach for rapid, accurate docking and scoring. 2. Enrichment factors in database screening. J. Med. Chem. 51, 69-82.

30. LigPrep (2013), Version 2.8, Core Hopping Schrodinger, LLC, New York, USA.

31. Lipinski, C.A., Lombardo, F., Dominy, B.W. and Feeney, P.J. 1997. Experimental and computational approaches to estimate solubility and permeability in drug discovery and development settings. Adv. Drug Deliv. Rev. 23 (1-3), 3-25.
32. Owens, J. and Lipinski, C. 2003. Chris Lipinski discusses life and chemistry after rule of five. Drug Discov. Today 8, 1216.

33. Chohan, K.K., Paine, S.W. and Waters, N.J. 2008. Advancements in predictive in silico models for ADME. Curr. Chem. Bio. 2, 215-228.

34. Korzekwa, K.R., Jones, J.P. and Gillette, J.R. 1990. Theoretical-studies on cytochrome-p-450 mediated hydroxylation - a predictive model for hydrogen-atom abstractions. J. Am. Chem. Soc. 112, 7042-7046.

35. Harwood, Laurence M. and Moody, Christopher J. 1989. Experimental organic chemistry: Principles and Practice (Illustrated edition). Wiley-Blackwell, pp. 122-125. ISBN 0632-02017-2.

36. Meyer, B.N., Ferrighi, N.R., Putnam, J.E., Jacobsen, L.B., Nichols, D.E. and McLaughlin, J.L. 1982. Brine shrimp: a convenient general bioassay for active plant constituents. Planta Med. 45, 31-34.

37. Roy, P.P. and Roy, K. 2010. Molecular docking and QSAR studies of aromatase inhibitor androstendione derivatives. J. Pharm. Pharmacol. 62, 1717-1728

38. Nagar, S. and Saha, A. 2010. Exploring benzcyclo derivatives as potent aromatase inhibitors using ligand-based modeling studies. Eur. J. Med. Chem. 45, 4307-4315.

39. Chasanah U., Rachmawati, H., Febriana, V., Wulandari, F.T., Sikdewa, S.B., Amalia, R., Debby, A.S., Jamil, A.S., 2012. Anti cancer pre-screening for several plants using brine shrimp lethality test. Proc. Intl. Conf. Drug Devel. Natul. Reso. pp. 25-29, ISBN : 978-979-18458-5-4. https://www.researchgate.net/publication/326586044 (article visited on 12 May 2020). 